\title{
THE IMPACT OF FREEZING METHODS ON FUNCTIONAL AND TECHNOLOGICAL PROPERTIES OF SEMI-FINISHED RABBIT MEAT PRODUCTS
}

\author{
Dodo Tavdidishvili, Davit Tsagareishvili, Tsira Khutsidze, Manana Pkhakadze, Lana Kvirikashvili
}

\begin{abstract}
During storage meat and semi-finished meat products, the decisive factor is the correct implementation of freezing process, because the physical, histological, biochemical, microbiological changes that occur at this time, affect the final quality of product after defrosting procedure. Accordingly, studies of the impact of traditional and shock-freezing methods on functional and technological properties of semi-finished rabbit meat products represent scientific and practical interest. The effect of freezing temperature of natural and minced semi-finished rabbit meat products on the duration of cold treatment process has been studied, and the regression equations of their relationships have been obtained and regression curves have been constructed. It has been established that unlike traditional method, by the type of semi-finished products, the duration of cold treatment by shock-freezing method is $3-3.5$ times shorter. The optimal freezing parameters have also been selected. It has been shown that the use of shock-freezing method contributes to the reduction of mass losses of semi-finished rabbit meat products, and by the type of semi-finished products, they are 5-5.3 lower as compared to traditional method of freezing. The determination of functional properties has revealed that shock-freezing allows for increasing water binding capacity-by $23.2-31.9 \%$, water holding capacity-by $20-25 \%$ and $\mathrm{pH}$ by $6.7-10.4 \%$. There have been studied microbiological indicators of frozen semi-finished products and their changes during the storage process. It has been established that they meet the safety and hygiene requirements for meat products. The full results obtained indicate the advantage of shockfreezing method as compared to traditional methods, as well as point to the appropriateness of its use when selecting the cold treatment modes for semi-finished rabbit meat products.
\end{abstract}

Keywords: rabbit meat; shock freezing; semi-finished products; functional properties; microbiological indicators

\section{INTRODUCTION}

The most important problem of modernity is to meet the population's needs for high quality and safe food products.

With a view to preserving the quality of foodstuffs and their safe storing for an extended period of time, of particular importance is the use of modern refrigeration technologies and the development of rational regimes cold treatment (Bolshakov, 2003; Feiner, 2010; Hip, 2007; Erlihman, 2010; Evans, 2008; Farouk, Wieliczko and Merts, 2004).

During storage meat and meat products, as well as other perishable food raw materials, the decisive factor is the correct implementation of freezing process, because the physical, histological, biochemical, microbiological changes that occur at this time, affect the final quality of product after defrosting procedure (Rogov, Zabashta and Kazyulin, 2009; Vieira et al., 2009; Gambuteanu, Borda and Alexe, 2013; Chwastowska-Siwiecka et al., 2013; Swami, Raut and Rindhe, 2015; Wang, He and Li, 2018).
When refrigerating meat and semi-finished meat products, the decisive factor, coupled with a temperature, is the rate of freezing. The process of crystallization of moisture existing in product, the sizes of generated ice crystals, their distribution in tissues and, consequently, maintaining the integrity of the tissue's natural structure, as well enzymatic changes in tissue and recovery of primary properties in the process of defrosting, depend on the dynamics of cold penetration into the depth of product.

Resaerch investigations of various authors have confirmed that the increase in the sizes of ice crystals in the freezing process is directly linked to disruption of a cell structure of tissue, and the most share of disruption of tissue cells takes place during freezing at slow rate. However, in some of the works, it is noted that in the superfast freezing process, there also occur substantial mechanical destructions in the tissue (Jo et al., 2014; Onishchenko, Zheliba and Zinchenko, 2011; Leygonie, Britz and Hoffman, 2012). 
The quality of the frozen product is achieved by the dynamics of the decrease of product temperature. In this regard, attention should be given to meat, in which $60-75 \%$ of the total weight is liquid. Accordingly, the freezing and defrosting processes are based entirely on the state of a liquid phase of the product.

It is known that the freezing process using traditional method takes places at temperature minus $18{ }^{\circ} \mathrm{C}$ and at an air velocity of $0.1 \mathrm{~m} . \mathrm{s}^{-1}$. In the case of different cooling equipment and different products, the duration of the process is $2.5-5$ hours. At that time, due to a low rate of freezing within a temperature range from 0 to $-5^{\circ} \mathrm{C}, 70 \%$ of mosture existing in product is transferred from the liquid phase into the solid phase, the crystallization process begins, and due to slow freezing, the crystals are getting larger, which is accompanied by a substantial disruption of a cell structure of tissue.

Today, the efficient freezing and shock-freezing technologies are considered to be a promising area among the methods of cold treatment of meat products. Unlike traditional method, shock-freezing, due to high rate and low temperature, reduces $3-5$ times the duration of freezing, prevents the increase in the sizes of crystals, considerably reduces mechanical destruction of tissue and contributes towards maintaining the structure of biological membrane. In addition, shock-freezing impedes bacteria development and activity, has a conservative impact on the natural autolytic processes of destruction of the protein structures (Filippov, Kremenevskaya and Kutsakova, 2014; Evans, 2008; Soroko and Usenia, 2011; Qian et al., 2018).

Thus, the lower the meat freezing and storage temperature, the less change in the tissue structure caused by moisture redistribution and the increase in the liquid phase concentration, which is reflected in binding capacity of water and the loss of cellular fluid and nutrients dissolved in this fluid.

It should be noted that there are limited scientific data in the literature on the impact of freezing conditions on technological and functional properties on rabbit meat semifinished products.

Based on the above, the goal of our study is to investigate the impact of different conditions of cold treatment of rabbit meat semi-finished products on the duration of freezing process and the functional-technological characteristics of semi-finished products.

\section{Scientific hypothesis}

By shortening the duration of freezing process, the shockfreezing method improves the functional-technological characteristics of product, with respect to the traditional method.

\section{MATERIAL AND METHODOLOGY}

The studies were carried out in the laboratories of the Department of Food of Akaki Tsereteli State University. Research covered semi-finished products produced from rabbit meat of Californian breed (their average age was 130 days): 1 - piece of rabbit meat - fillet; 2 - minced, made by traditional recipe; 3 - minced semi-finished product enriched with a plant-based supplement. As a plant-based supplement there was used lentil puree in the amount of $25-30 \%$ by mass of meat. The mass of all samples was $100 \mathrm{~g}$, and the thickness was $20 \mathrm{~mm}$.

The semi-finished products were frozen using the following methods: traditional freezing (freezing temperatures $-\mathrm{T}=-18{ }^{\circ} \mathrm{C}$, air velocity $-\mathrm{V}=0.1 \mathrm{~m} \cdot \mathrm{s}^{-1}$ and relative humidity $-\varphi=85 \%$ ), intermediate freezing (freezing temperatures $-\mathrm{T}=-30{ }^{\circ} \mathrm{C}$, air velocity $\mathrm{V}=0.1 \mathrm{~m} . \mathrm{s}^{-1}$ and relative humidity $-\varphi=85 \%$ ), and shockfreezing (freezing temperatures $-\mathrm{T}=-30{ }^{\circ} \mathrm{C}$, air velocity $\mathrm{V}=9.4 \mathrm{~m} \cdot \mathrm{s}^{-1}$ and relative humidity $-\varphi=87 \%$ ), The freezing was carried out in a chest freezer in the wardrobe (KLIMASAN) at $-18{ }^{\circ} \mathrm{C}$, at an air velocity of $0.1 \mathrm{~m} . \mathrm{s}^{-1}$ and in a shock-freezing fridge (ATTILA GN 1/1 $600 \times 400 \mathrm{~mm})$ at $-35{ }^{\circ} \mathrm{C}$, at an air velocity of $9.4 \mathrm{~m} . \mathrm{s}^{-1}$.

The freezing temperature in samples was determined by contact thermocouple thermodynamics (DIGITAL MULTIMETER DT9208A, the measuring range $-40{ }^{\circ} \mathrm{C}-1370{ }^{\circ} \mathrm{C}$, measurement error $-1.5 \%$ ). The product was considered frozen, when the temperature of product was fixed at minus $10^{\circ} \mathrm{C}$.

The mass losses during freezing and thermic treatment, we determined by the mass difference after the cold and thermic treatment of samples, water binding capacity - by press method of Grau and Hamm, water-holding capacity by the difference between the amounts of moisture existing in semi-finished product and moisture released during thermic treatment (Antipova, Glotova and Rogov, 2004), the $\mathrm{pH}$ medium was determined by potentiometric method.

Organoleptic indicators were determined based on a 10-point system, according to the following characteristics: appearance, color, smell, taste, consistency and succulence.

During microbiological analysis, the quantities of mesophylic aerobic and facultative anaerobic microorganisms in rabbit meat were determined according to state standard "Food products. Methods for determining the quantities of mesophylic aerobic and facultative anaerobic microorganisms" - GOST 10444.15-94 (1994); number of bacteria of intestinal bacillus was determined according to State Standard "Food products. Methods for the detection and determination of the number of bacteria of the Escherichia coli group (coliform bacteria)" - GOST 30518-97 (1997); Salmonella was determined according to State standard "Food products. Methods for the detection of bacteria of the genus Salmonella" - GOST 30519-97 (1997).

\section{Statistic analysis}

To analyze the test parameters (mass losses, water binding and Water holding capacity) of rabbit meat, is conducted a statistical analysis of the obtained data, the reliability of the obtained data was evaluated by the mathematical statistics method T-test using the Windows IBM SPSS Statistics software program (version 20.0). To describe the ordered sample, we used statistical functions of the average arithmetic value and average standard error.

Graphical interpretation of the results was made by using Microsoft Excel. In Table 1, Table 2, Table 3, Table 4, Table 5 and Figure 1, Figure 2, Figure 3 and Figure 4, there are presented the data of typical tests, and each value is an average of at least ten determinations. 


\section{RESULTS AND DISCUSSION}

In line with the target, using the different methods of freezing at the first stage of research, we determined the effect of freezing temperature of samples on the duration of their cold treatment. The results are shown in Figure 1A, Figure 1B, Figure 2A, Figure 2B, and Figure 3A, Figure 3B.

Figure 1A, Figure 1B, Figure 2A, Figure 2B and Figure $3 \mathrm{~A}$ and Figure $3 \mathrm{~B}$ illustrate that the process of cold treatment is significantly affected by the parameters, such as temperature and air velocity.

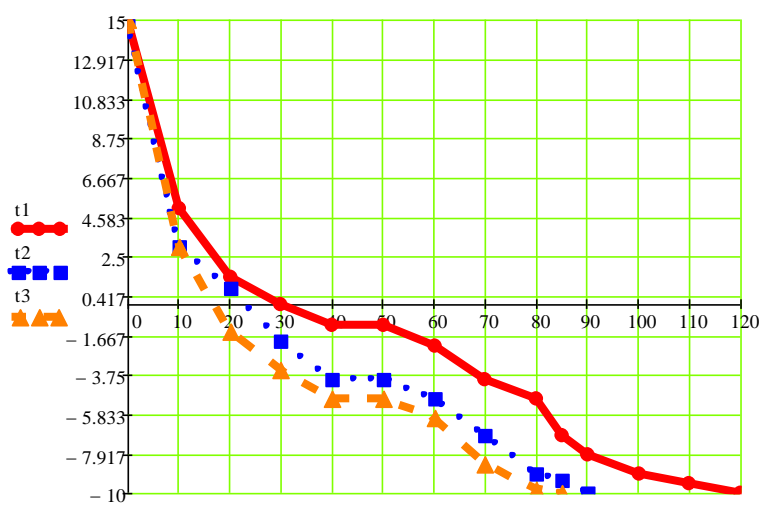

Figure 1A The effect of freezing temperature on the duration of freezing of semi-finished products during cold treatment by traditional freezing method.

Note: $\left(\mathrm{T}=-18{ }^{\circ} \mathrm{C}, \mathrm{V}=0.1 \mathrm{~m} \cdot \mathrm{s}^{-1}, \varphi=85 \%\right)$,

1. fillet,

2. natural minced semi-finished product,

3. minced semi-finished product enriched with a plant-based supplement.

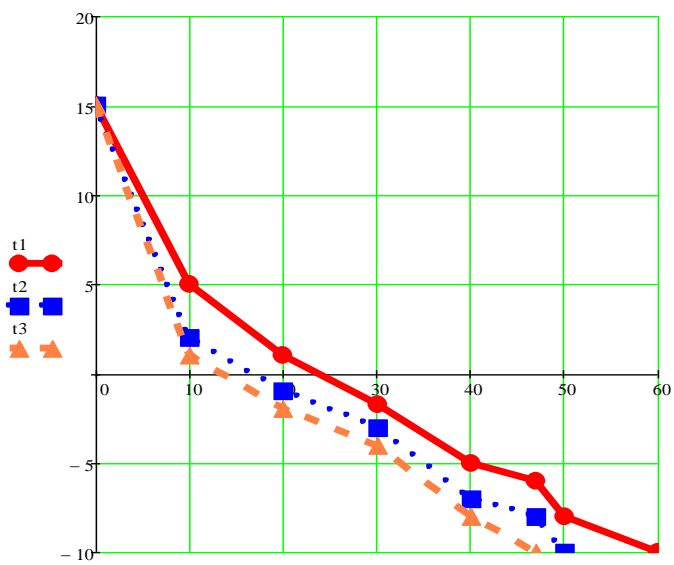

Figure 2A The effect of freezing temperature on the duration of freezing of semi-finished products during cold treatment by intermediate freezing method.

Note: $\left(\mathrm{T}=-30{ }^{\circ} \mathrm{C}, \mathrm{V}=0.1 \mathrm{~m} \cdot \mathrm{s}^{-1}, \varphi=85 \%\right)$,

1. fillet,

2. Natural minced semi-finished product,

3. minced semi-finished product enriched with a plant-based supplement.

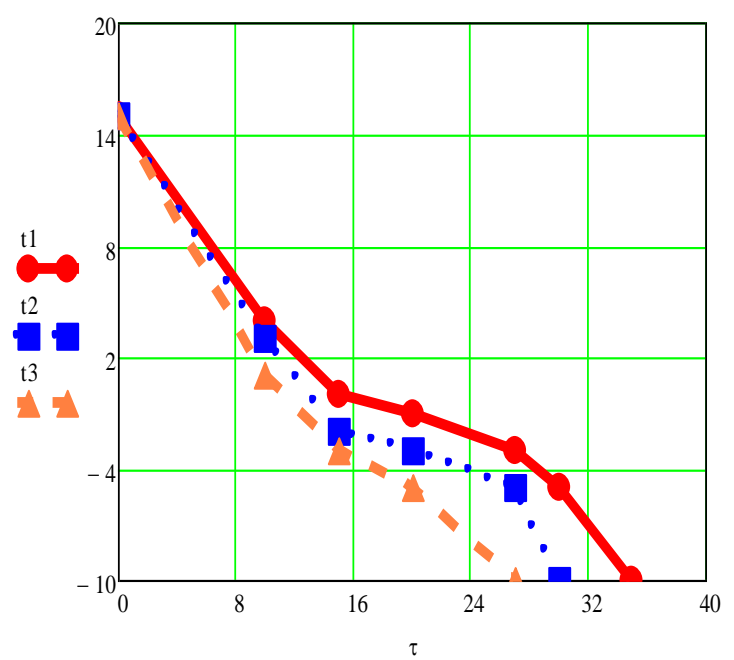

Figure 3A The effect of freezing temperature on the duration of freezing of semi-finished products during cold treatment by shock-freezing method.

Note: $\left(\mathrm{T}=-30{ }^{\circ} \mathrm{C}, \mathrm{V}=9.4 \mathrm{~m} \cdot \mathrm{s}^{-1}, \varphi=87 \%\right)$,

1. fillet,

2. natural minced semi-finished product,

3. minced semi-finished product enriched with a plant-based supplement.

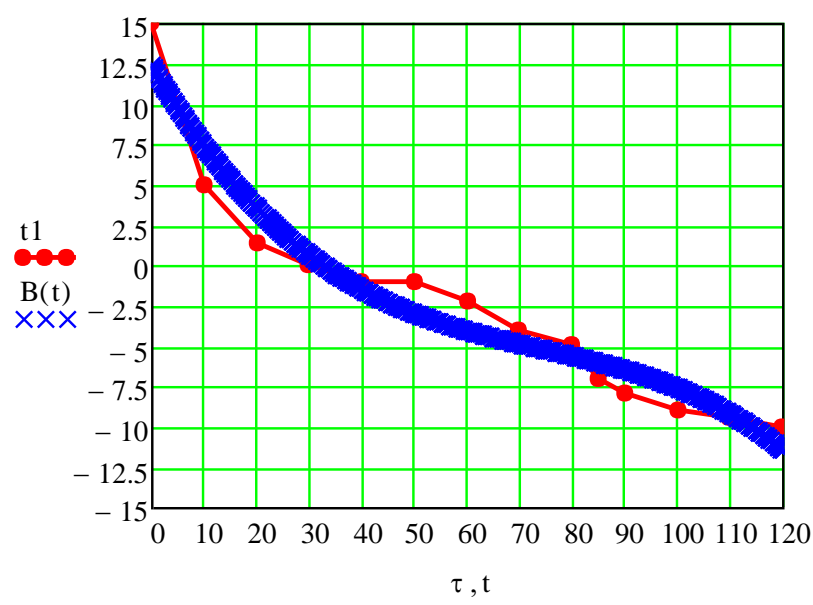

Figure 1B The effect of freezing temperature on the duration of freezing of semi-finished products during cold treatment by traditional freezing method.

$\underset{\mu}{\mathrm{b}}:=$ regress $(\tau, \mathrm{t} 1,3)$

correlation coefficient

$\operatorname{corr}(\tau, \mathrm{t} 1)=-0.961$

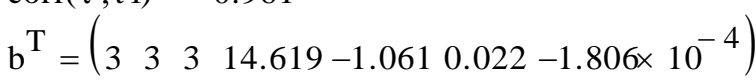

Regression coefficient

$\mathrm{B}(\mathrm{t}):=\operatorname{interp}(\mathrm{b}, \tau, \mathrm{t} 1, \mathrm{t})$

a $:=\operatorname{line}(\tau, \mathrm{t} 1) \mathrm{a}=\left(\begin{array}{c}10.857 \\ -0.379\end{array}\right)$

the equation of the regression line

$\underset{\text { s }}{\mathrm{f}}(\mathrm{y}):=\mathrm{a}_{0}+\mathrm{a}_{1} \cdot \mathrm{y}$

Diagram of the approximation dependencies 


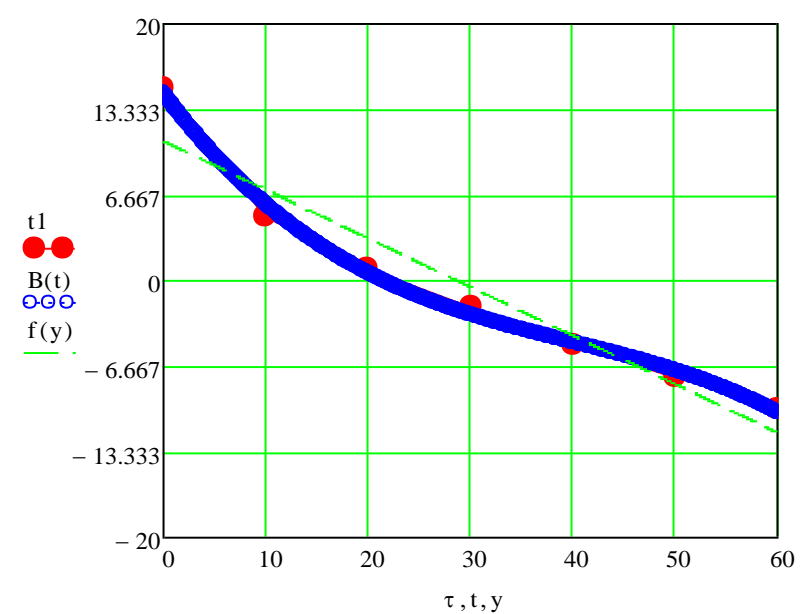

Figure 2B The effect of freezing temperature on the duration of freezing of semi-finished products during cold treatment by intermediate freezing method.

$\underset{\mu \mu i}{\mathrm{~b}}:=$ regress $(\tau, \mathrm{t} 1,3)$

correlation coefficient

$\mathrm{b}^{\mathrm{T}}=\left(\begin{array}{llllll}3 & 3 & 3 & 15.165-1.631 & 0.061 & -9.975 \times 10^{-4}\end{array}\right)$

$\mathrm{a}=\left(\begin{array}{c}10.857 \\ -0.379\end{array}\right)$

Regression coefficient

$\underset{\mu}{\mathrm{B}}(\mathrm{t}):=\operatorname{interp}(\mathrm{b}, \tau, \mathrm{t} 1, \mathrm{t})$

$\underset{\mathrm{a}}{\mathrm{a}}:=\operatorname{line}(\tau, \mathrm{t} 1)$

the equation of the regression line

$\underset{s y}{\mathrm{f}}(\mathrm{y}):=\mathrm{a}_{0}+\mathrm{a}_{1} \cdot \mathrm{y}$

Diagram of the approximation dependencies

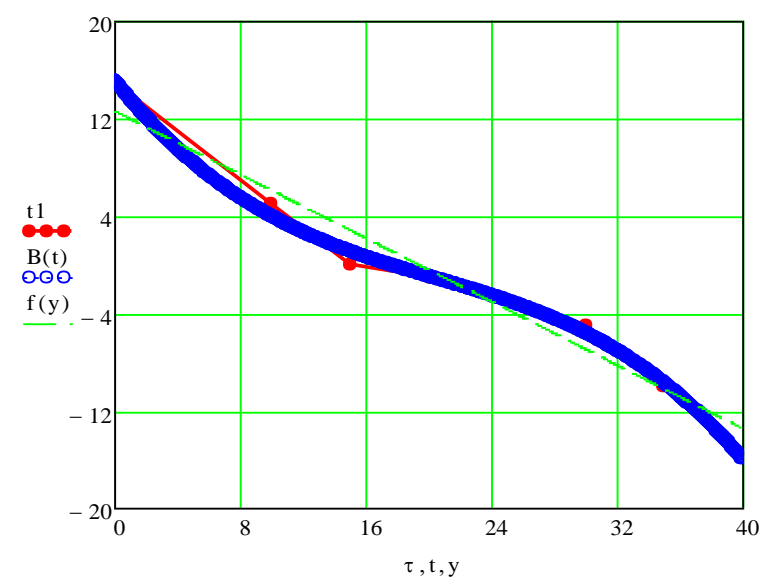

Figure 3B The effect of freezing temperature on the duration of freezing of semi-finished products during cold treatment by shock-freezing method.

We selected the value of reliability $p=0.05$. In particular, the duration of freezing process in the case of shockfreezing is shortened relative to traditional method: 85 minutes off for rabbit meat fillet, 60 minutes off for natural minced semi-finished product, and 58 minutes off for minced semi-finished product enriched with a plant-based supplement. The difference between the freezing durations of different samples is explained by the different structures and compositions of samples.
A similar trend is reported in the data obtained by other authors (Tsikin, 2012; Yablonenko, 2008; Ali et al., 2015; Jo et al., 2014) in freezing similar semi-finished products produced from studied beef and pork, while in the case of rabbit meat, the obtained data are much better. This can be explained by the low content of fat in rabbit meat, the amount of which affects the duration of freezing.

Qualitative indicators of products (structure, storage stability and yield) are especially affected by the moisture content in them. Thus, at the next stage of research, we studied the functional-technological properties of samples: mass losses, water binding and water holding capacity of the study samples: mass losses, water connectivity and water retention capacity.

Table 1 and Table 2 outline the data on mass losses of the test samples under various cold treatment conditions and after thermic treatment.

The tables indicate that mass losses are as minimal in both cases of cold treatment and further thermic treatment, while using a shock-freezing method, and respectively, they are: for fillet $-0.7 \%$ and $9.5 \%$; in the case of natural minced semi-finished products $-0.85 \%$ and $11.4 \%$; while for minced semi-finished products enriched with a plant-based supplement $-0.75 \%$ and $10.2 \%$.

In addition, under shock-freezing conditions, mass losses in minced rabbit meat semi-finished products are higher than in fillet, in particular, by $21.4 \%$. In natural minced semi-finished products, while in minced semi-finished products enriched with a plant-based supplement, mass losses are $7.1 \%$ higher than in fillet, which is explained by a larger content of "free water" in fillet.

For their part, mass losses in fillet during shock-freezing are five times lower than during freezing by traditional method, while in minced semi-finished products - by 5.29 and 5.33 times, respectively. After thermic treatment of the test samples, the same data are reduced by $1.72,1.58$ and 1.69 times, respectively (Table 2).

It is well known that mass losses after thermic treatment of semi-finished products are linked to water binding capacity, while the organoleptic indicators of the finished products (succulence, consistency, appearance) depend on water holding capacity of semi-finished products.

Water binding and water holding capacities of the test samples in different freezing conditions are shown in Table 3 and Table 4.

The Table 3 and Table 4 illustrate that water binding and water holding capacities of the test samples are better in shock-freezing conditions.

The figures in tables illustrate that water binding and water holding capacities of the test samples are better in shockfreezing conditions. In comparison with traditional freezing method, water binding capacity of fillet has increased by $31.9 \%$, while water holding capacity has increased by $25 \%$, in natural minced semi-finished products - by $23,2 \%$ and $20 \%$, respectively, and in minced semi-finished products enriched with a plant-based supplement - by $24,5 \%$ and $20,9 \%$, respectively.

The better functional and technical indicators obtained by shock-freezing method show that of ice crystals formed during the fast freezing process have a minimal impact on a cell structure of rabbit meat tissue, at that time, no structural destruction of tissue and biological membranes is happening, so water crystals destroy the structure of tissues, 
there is a change of hydrophilic properties of tissue and destruction of the protein-water colloidal systems, resulting in reduced water binding capacity (Tsikin, 2012; Yablonenko, 2008).

In addition, as compared with other semi-finished products, higher water binding and water holding capacities of minced semi-finished products enriched with a plantbased supplement, is presumably explained by the fact that water is held due to a substantial amount of starch and fiber fetlock existing in a plant-based supplement (Tavdidishvili et al., 2018).

The obtained data on water binding and water holding capacities of the test samples are in line with similar data obtained by other authors during the freezing of beef, pork and poultry meat. For example, according to Tsikin (2012), the lowest water binding and water holding capacities were found in those samples, which were frozen at minus $30^{\circ} \mathrm{C}$ and at an air velocity of $9.4 \mathrm{~m} \cdot \mathrm{s}^{-1}$.

We have also studied the variation of $\mathrm{pH}$ medium of minced semi-finished rabbit meat products during different modes of freezing (Figure 4).

As shown in Figure 4 the $\mathrm{pH}$ medium value for both samples, in all freezing conditions is within the required limits, and besides, under shock-freezing conditions, its value is $6.7-10.4 \%$ higher, indicating the advantage of this method.

At the next stage of the study, we studied the organoleptic indices of frozen minced semi-finished products after their thermic treatment. The results are presented on the profilograms (Figure 5 and Figure 6).
At the same time, the organoleptic indices of minced semifinished rabbit meat products are enriched with a plant-

The profilograms show that the organoleptic indices of both samples of minced semi-finished products are better than under shock-freezing conditions.

At the sme time, the organoleptic indices of minced semifinished rabbit meat products are enriched with a plantbased supplement are better than the organoleptic indices of natural minced semi-finished products, particularly, their higher succulence is explained by relatively higher water holding capacity of minced semifinished products enriched with a plant-based supplement ability.

We have determined microbiological indicators of the test samples frozen by various methods (Table 5).

Microbiological analysis was carried out on the presence of mesophylic-aerobic and facultative anaerobic microorganisms, salmonellas and bacteria of intestinal bacillus. It has been established that in test samples, the quantities of mesophylic aerobic and facultative anaerobic microorganisms varied from $3.4 \cdot 10^{2}$ to $2.4 \cdot 10^{3} \mathrm{CFU}_{\mathrm{g}^{-1}}$ (colony forming unit. $\mathrm{g}^{-1}$ ) that does not exceed sanitary norms and rules.

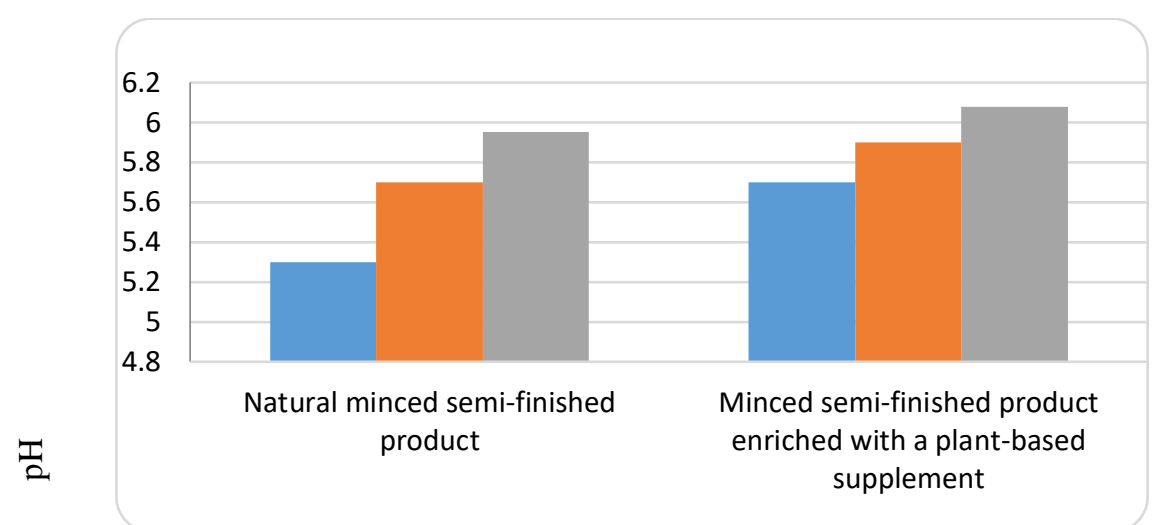

Figure 4 Change in the value of $\mathrm{pH}$ medium in minced semi-finished rabbit meat products in various modes of freezing.
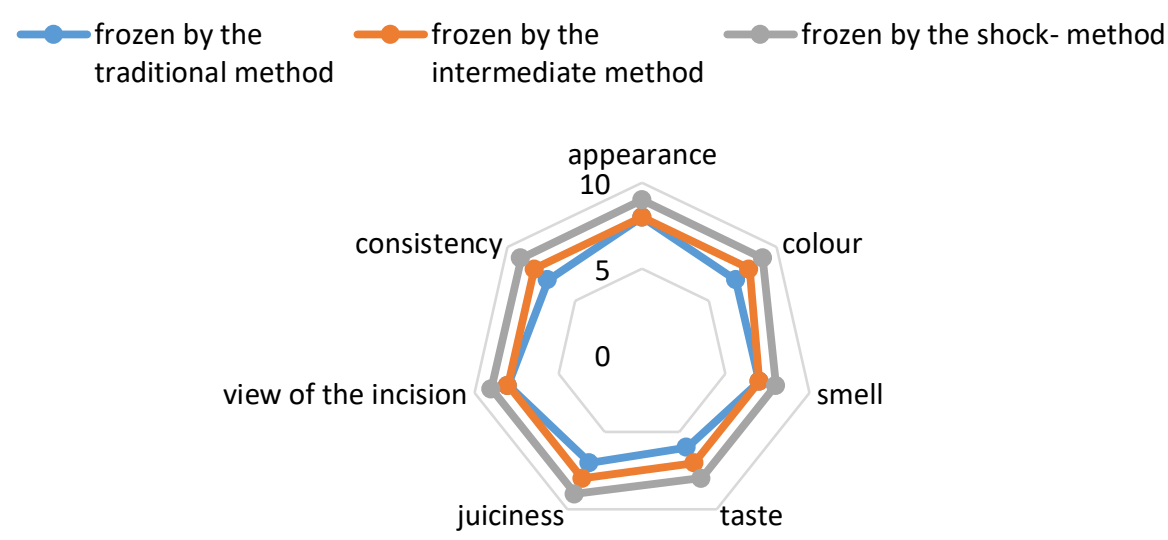

Figure 5 Profilogram of organoleptic indices of frozen natural minced semi-finished products after their thermic treatment. 
Potravinarstvo Slovak Journal of Food Sciences

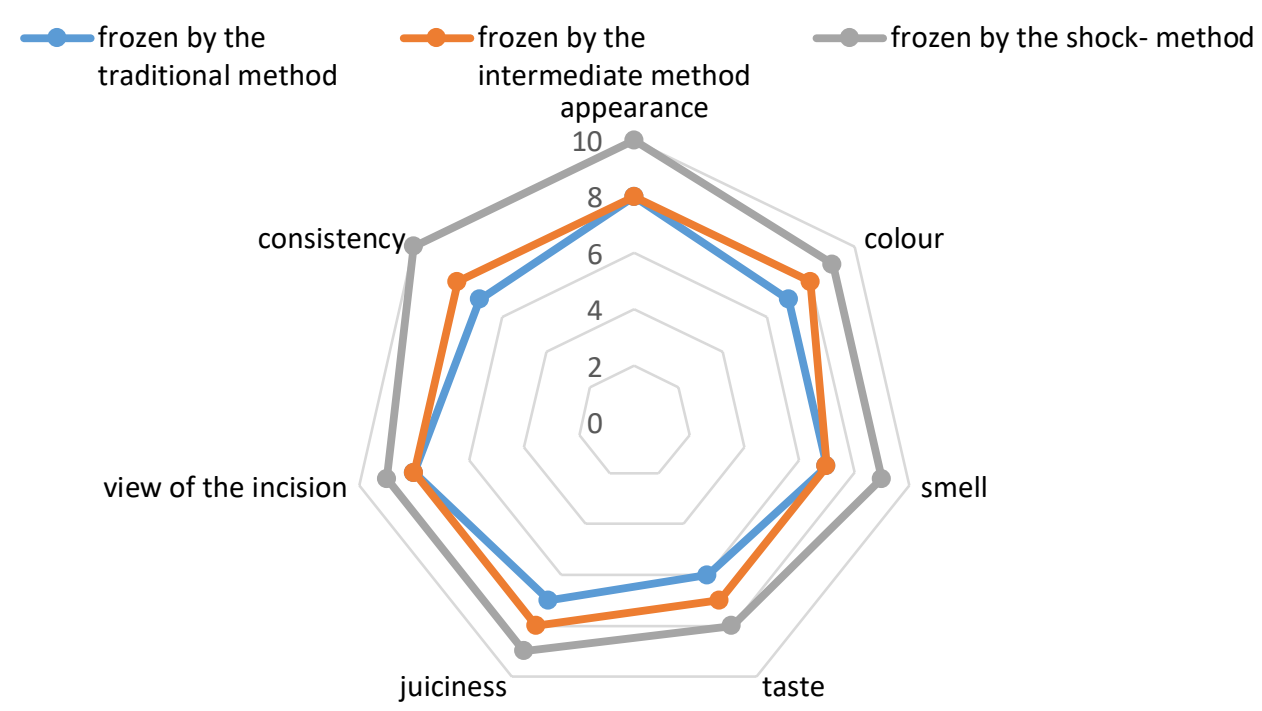

Figure 6. Profilogram of organoleptic indices of frozen minced semi-finished products enriched with a plant-based supplement after their thermic treatment

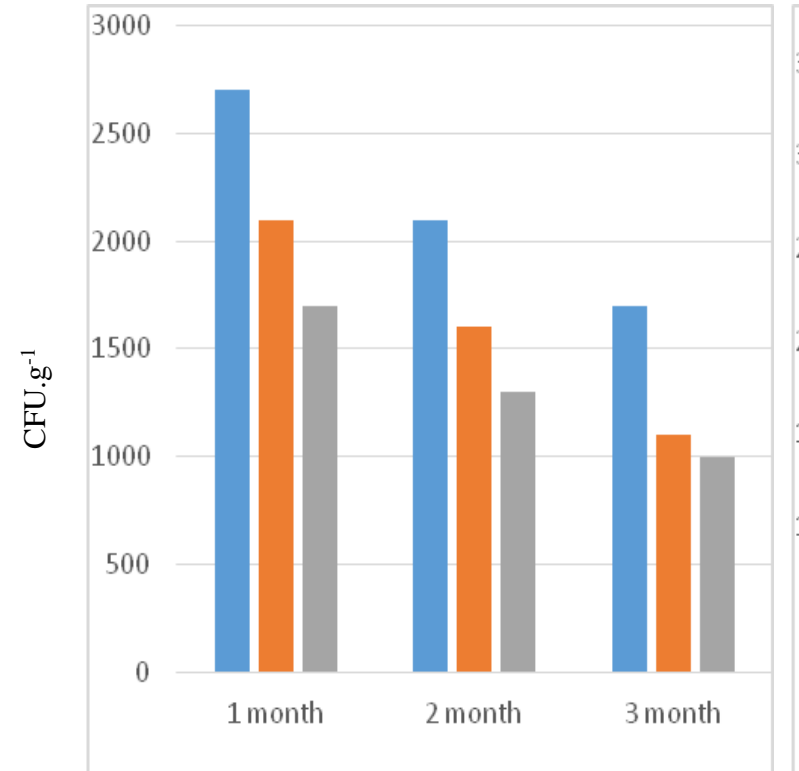

a) Duration of storage, month

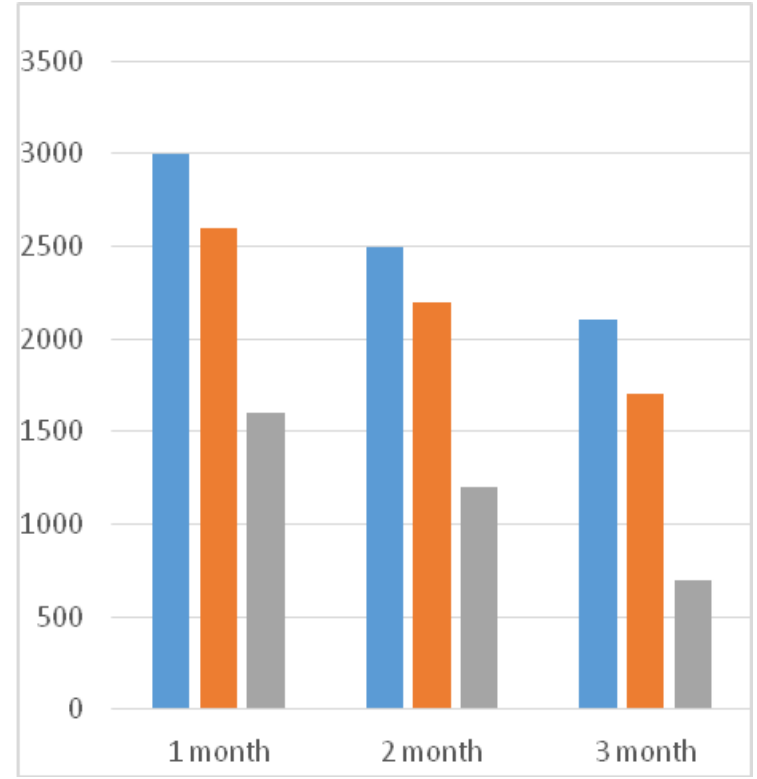

b)
Duration of storage, month

$$
\begin{aligned}
& \mathbf{T}==-18^{\circ} \mathrm{C}, \mathrm{V}=0,1 \mathrm{~m} / \mathrm{sec} \\
& \mathrm{T}=-30^{\circ} \mathrm{C}, \mathbf{V}=0,1 \mathrm{~m} / \mathrm{sec} \\
& \mathrm{T}=-30{ }^{\circ} \mathrm{C}, \mathrm{V}=9,4 \mathrm{~m} / \mathrm{sec}
\end{aligned}
$$

Figure 7. Changes in mezophilic-aerobic and facultative-anaerobic microorganisms $\left(\mathrm{CFU} \cdot \mathrm{g}^{-1}\right)$ during the storage process: a) in natural minced semi-finished products; b) in minced semi-finished products enriched with a plant-based supplement in various modes of freezing. 
Table 1 Mass losses of rabbit meat fillet and minced semi-finished products under various freezing conditions.

\begin{tabular}{|c|c|c|c|}
\hline \multirow[b]{2}{*}{$\begin{array}{l}\text { Semi-finished } \\
\text { products of rabbit meat }\end{array}$} & \multicolumn{3}{|c|}{ Change of mass after freezing, \% } \\
\hline & $\begin{array}{c}\mathrm{T}=-18{ }^{0} \mathrm{C} \\
\mathrm{V}=0.1 \mathrm{~m} \cdot \mathrm{sec}^{-1}\end{array}$ & $\begin{array}{c}\mathrm{T}=-30^{0} \mathrm{C} \\
\mathrm{V}=0.1 \mathrm{~m} \cdot \mathrm{sec}^{-1}\end{array}$ & $\begin{array}{c}\mathrm{T}=-30^{0} \mathrm{C} \\
\mathrm{V}=9.4 \mathrm{~m} \cdot \mathrm{sec}^{-1}\end{array}$ \\
\hline Fillet & 3.5 & 1.6 & 0.7 \\
\hline $\begin{array}{l}\text { Natural minced semi-finished } \\
\text { product }\end{array}$ & 4.5 & 2.15 & 0.85 \\
\hline $\begin{array}{l}\text { Minced semi-finished product } \\
\text { enriched with a plant-based } \\
\text { supplement }\end{array}$ & 4.0 & 1.8 & 0.75 \\
\hline
\end{tabular}

Table 2 Mass losses of rabbit meat fillet and minced semi-finished products frozen under various conditions after thermic treatment.

\begin{tabular}{lccc}
\hline \multirow{2}{*}{$\begin{array}{l}\text { Semi-finished } \\
\text { products of rabbit meat }\end{array}$} & \multicolumn{2}{c}{ Change of mass after thermic treatment, \% } \\
\cline { 2 - 4 } & $\mathrm{T}=-18{ }^{0} \mathrm{C}$, & $\mathrm{T}=-30{ }^{0} \mathrm{C}$, & $\mathrm{T}=-30{ }^{0} \mathrm{C}$, \\
$\mathrm{V}=0.1 \mathrm{~m} \cdot \mathrm{sec}^{-1}$ & $\mathrm{~V}=0.1{\mathrm{~m} \cdot \mathrm{sec}^{-1}}^{-1}$ & $9.4 \mathrm{~m}^{-\mathrm{sec}^{-1}}$ \\
\hline $\begin{array}{l}\text { Fillet } \\
\begin{array}{l}\text { Natural minced semi-finished } \\
\text { product }\end{array}\end{array}$ & 16.4 & 13.0 & 9.5 \\
$\begin{array}{l}\text { Minced semi-finished product } \\
\text { enriched with a plant-based }\end{array}$ & 18.0 & 14.5 & 11.4 \\
supplement & 17.2 & & 10.2 \\
\hline
\end{tabular}

Table 3 Water binding capacity of rabbit meat fillet and minced semi-finished products under various freezing conditions.

\begin{tabular}{|c|c|c|c|}
\hline \multirow[b]{2}{*}{$\begin{array}{l}\text { Semi-finished } \\
\text { products of rabbit meat }\end{array}$} & \multicolumn{3}{|c|}{ Change of water binding capacity from the total mass, \% } \\
\hline & $\begin{array}{c}\mathrm{T}=-18^{\circ} \mathrm{C} \\
\mathrm{V}=0.1 \mathrm{~m} \cdot \mathrm{sec}^{-1}\end{array}$ & $\begin{array}{c}\mathrm{T}=-30^{\circ} \mathrm{C} \\
\mathrm{V}=0.1 \mathrm{~m} \cdot \mathrm{sec}^{-1}\end{array}$ & $\begin{array}{c}\mathrm{T}=-30^{\circ} \mathrm{C} \\
\mathrm{V}=9.4 \mathrm{~m} \cdot \mathrm{sec}^{-1}\end{array}$ \\
\hline Fillet & 47 & 55 & 62 \\
\hline $\begin{array}{l}\text { Natural minced semi-finished } \\
\text { product }\end{array}$ & 56 & 60 & 69 \\
\hline $\begin{array}{l}\text { Minced semi-finished product } \\
\text { enriched with a plant-based } \\
\text { supplement }\end{array}$ & 57 & 63 & 714 \\
\hline
\end{tabular}

Table 4 Water holding capacity of rabbit meat fillet and minced semi-finished products under various freezing conditions.

\begin{tabular}{lccc}
\hline $\begin{array}{l}\text { Semi-finished } \\
\text { products of rabbit meat }\end{array}$ & \multicolumn{3}{c}{ Change of water holding capacity, \% } \\
\cline { 2 - 4 } & $\begin{array}{r}\mathrm{T}=-18{ }^{0} \mathrm{C}, \\
\mathrm{V}=0.1 \mathrm{~m}_{\mathrm{sec}} \mathrm{se}^{-1}\end{array}$ & $\begin{array}{r}\mathrm{T}=-30{ }^{0} \mathrm{C}, \\
\mathrm{V}=0.1 \mathrm{~m}_{\mathrm{sec}}^{-1}\end{array}$ & $\begin{array}{c}\mathrm{T}=-30{ }^{0} \mathrm{C}, \\
\mathrm{V}=9.4 \mathrm{~m}^{-1} \mathrm{sec}^{-1}\end{array}$ \\
\hline Fillet & 52 & 60 & 65 \\
$\begin{array}{l}\text { Natural minced semi-finished } \\
\text { product }\end{array}$ & 60 & 63 & 72 \\
$\begin{array}{l}\text { Minced semi-finished product } \\
\text { enriched with a plant-based } \\
\text { supplement }\end{array}$ & 62 & 65 & 75 \\
\hline
\end{tabular}


Table 5 Microbiological indicators of the test samples frozen by with different methods and their changes during the storage process.

\begin{tabular}{|c|c|c|c|c|c|c|}
\hline \multirow{3}{*}{$\begin{array}{l}\text { microbiological } \\
\text { indicators }\end{array}$} & \multicolumn{6}{|c|}{ Name of Product } \\
\hline & \multicolumn{2}{|c|}{ fillet } & \multicolumn{2}{|c|}{$\begin{array}{l}\text { natural minced semi- } \\
\text { finished products }\end{array}$} & \multicolumn{2}{|c|}{$\begin{array}{l}\text { minced semi-finished } \\
\text { products enriched with a } \\
\text { plant-based supplement }\end{array}$} \\
\hline & $\begin{array}{l}\text { before } \\
\text { freezing }\end{array}$ & $\begin{array}{c}\text { after } \\
\text { freezing }\end{array}$ & $\begin{array}{l}\text { before } \\
\text { freezing }\end{array}$ & $\begin{array}{c}\text { after } \\
\text { freezing }\end{array}$ & $\begin{array}{l}\text { before } \\
\text { freezing }\end{array}$ & $\begin{array}{l}\text { after } \\
\text { freezing }\end{array}$ \\
\hline \multicolumn{7}{|c|}{ Frozen by the traditional method $\left(\mathrm{T}=-18^{0} \mathrm{C}, \mathrm{V}=0.1 \mathrm{~m} \cdot \mathrm{sec}^{-1}\right)$} \\
\hline $\begin{array}{l}\text { Number of mesophilic- } \\
\text { aerobic and facultative- } \\
\text { anaerobic microorganisms, } \\
\text { cfu.g }{ }^{-1},(\text { colony-forming unit } \\
\text { per gram), less than }\end{array}$ & $2.4 * 10^{3}$ & $1.7 * 10^{3}$ & $3.6 * 10^{3}$ & $3.2^{*} 10^{3}$ & $4.0 * 10^{3}$ & $3.4 * 10^{3}$ \\
\hline $\begin{array}{l}\text { E. coli group bacteria, in a } \\
0.001 \mathrm{~g} \text { sample }\end{array}$ & $\begin{array}{l}\text { have not } \\
\text { been } \\
\text { identified }\end{array}$ & $\begin{array}{l}\text { have not } \\
\text { been } \\
\text { identified }\end{array}$ & $\begin{array}{l}\text { have not } \\
\text { been } \\
\text { identified }\end{array}$ & $\begin{array}{l}\text { have not } \\
\text { been } \\
\text { identified }\end{array}$ & $\begin{array}{l}\text { have not } \\
\text { been } \\
\text { identified }\end{array}$ & $\begin{array}{l}\text { have not } \\
\text { been } \\
\text { identified }\end{array}$ \\
\hline $\begin{array}{c}\text { Pathogenic } \\
\text { microorganisms, including } \\
\text { Salmonella, in a } 25 \mathrm{~g} \\
\text { sample }\end{array}$ & $\begin{array}{l}\text { have not } \\
\text { been } \\
\text { identified }\end{array}$ & $\begin{array}{l}\text { have not } \\
\text { been } \\
\text { identified }\end{array}$ & $\begin{array}{l}\text { have not } \\
\text { been } \\
\text { identified }\end{array}$ & $\begin{array}{l}\text { have not } \\
\text { been } \\
\text { identified }\end{array}$ & $\begin{array}{l}\text { have not } \\
\text { been } \\
\text { identified }\end{array}$ & $\begin{array}{l}\text { have not } \\
\text { been } \\
\text { identified }\end{array}$ \\
\hline \multicolumn{7}{|c|}{ Frozen by the intermediate method $\left(\mathrm{T}=-30{ }^{0} \mathrm{C}, \mathrm{V}=0.1 \mathrm{~m} \cdot \mathrm{sec}^{-1}\right)$} \\
\hline $\begin{array}{l}\text { Number of mesophilic- } \\
\text { aerobic and facultative- } \\
\text { anaerobic microorganisms, } \\
\text { cfu.g }{ }^{-1},(\text { colony-forming } \\
\text { unit per gram), less than }\end{array}$ & $2.4 * 10^{3}$ & $1.3 * 10^{3}$ & $3.6 * 10^{3}$ & $2.7 * 10^{3}$ & $4.0 * 10^{3}$ & $3.0 * 10^{3}$ \\
\hline $\begin{array}{l}\text { E. coli group bacteria, in a } \\
0.001 \mathrm{~g} \text { sample }\end{array}$ & $\begin{array}{l}\text { have not } \\
\text { been } \\
\text { identified }\end{array}$ & $\begin{array}{l}\text { have not } \\
\text { been } \\
\text { identified }\end{array}$ & $\begin{array}{l}\text { have not } \\
\text { been } \\
\text { identified }\end{array}$ & $\begin{array}{l}\text { have not } \\
\text { been } \\
\text { identified }\end{array}$ & $\begin{array}{l}\text { have not } \\
\text { been } \\
\text { identified }\end{array}$ & $\begin{array}{l}\text { have not } \\
\text { been } \\
\text { identified }\end{array}$ \\
\hline $\begin{array}{c}\text { Pathogenic } \\
\text { microorganisms, including } \\
\text { Salmonella, in a } 25 \mathrm{~g} \\
\text { sample }\end{array}$ & $\begin{array}{l}\text { have not } \\
\text { been } \\
\text { identified }\end{array}$ & $\begin{array}{l}\text { have not } \\
\text { been } \\
\text { identified }\end{array}$ & $\begin{array}{l}\text { have not } \\
\text { been } \\
\text { identified }\end{array}$ & $\begin{array}{l}\text { have not } \\
\text { been } \\
\text { identified }\end{array}$ & $\begin{array}{l}\text { have not } \\
\text { been } \\
\text { identified }\end{array}$ & $\begin{array}{l}\text { have not } \\
\text { been } \\
\text { identified }\end{array}$ \\
\hline \multicolumn{7}{|c|}{ Frozen by the shock- freezing method $\left(\mathrm{T}=-30{ }^{0} \mathrm{C}, \mathrm{V}=9.4 \mathrm{~m} \cdot \mathrm{sec}^{-1}\right)$} \\
\hline $\begin{array}{l}\text { Number of mesophilic- } \\
\text { aerobic and facultative- } \\
\text { anaerobicmicroorganisms, } \\
\text { cfu.g }{ }^{-1},(\text { colony-forming } \\
\text { unit per gram), less than }\end{array}$ & $2.4 * 10^{3}$ & $0.7 * 10^{3}$ & $3.6 * 10^{3}$ & $2.1 * 10^{3}$ & $4.0^{*} 10^{3}$ & $2.0 * 10^{3}$ \\
\hline $\begin{array}{l}\text { E. coli group bacteria, in a } \\
0.001 \mathrm{~g} \text { sample }\end{array}$ & $\begin{array}{l}\text { have not } \\
\text { been } \\
\text { identified }\end{array}$ & $\begin{array}{l}\text { have not } \\
\text { been } \\
\text { identified }\end{array}$ & $\begin{array}{l}\text { have not } \\
\text { been } \\
\text { identified }\end{array}$ & $\begin{array}{l}\text { have not } \\
\text { been } \\
\text { identified }\end{array}$ & $\begin{array}{l}\text { have not } \\
\text { been } \\
\text { identified }\end{array}$ & $\begin{array}{l}\text { have not } \\
\text { been } \\
\text { identified }\end{array}$ \\
\hline $\begin{array}{c}\text { Pathogenic } \\
\text { microorganisms, including } \\
\text { Salmonella, in a } 25 \mathrm{~g} \\
\text { sample }\end{array}$ & $\begin{array}{l}\text { have not } \\
\text { been } \\
\text { identified }\end{array}$ & $\begin{array}{l}\text { have not } \\
\text { been } \\
\text { identified }\end{array}$ & $\begin{array}{l}\text { have not } \\
\text { been } \\
\text { identified }\end{array}$ & $\begin{array}{l}\text { have not } \\
\text { been } \\
\text { identified }\end{array}$ & $\begin{array}{l}\text { have not } \\
\text { been } \\
\text { identified }\end{array}$ & $\begin{array}{l}\text { have not } \\
\text { been } \\
\text { identified }\end{array}$ \\
\hline
\end{tabular}

The established value of bacteria of intestinal bacillus (coliform) was not in $0.01 \mathrm{~g}$ sample, and met the hygienic requirements of microbiological safety, but pathogenic microorganisms including salmonella, have not been detected in $25 \mathrm{~g}$ samples, which also complied with microbiological safety norms and indicates safety of product. The data in Table 5 also confirm that the method of shock-freezing reduces the contamination of semi- finished products by mezophilic-aerobic and facultativeanaerobic microorganisms.

We have explored the changes in microbiological indicators of the test samples frozen under different conditions during the storage process, after 1, 2 and 3 months, respectively (Figure 7).

It has been established that during this period, no coliform bacteria and salmonella were found in the test samples, while the dynamics of changes in mezophilic-aerobic and 
facultative-anaerobic microorganisms showed that, in the cases of all freezing methods, their value is reduced and is minimal when using the shock-freezing method.

Thus and so, studies have shown that method of shockfreezing allows for shortening the duration of freezing process, as compared to the traditional method, as well as for improving the functional-technological characteristics of product

\section{CONCLUSION}

With a view to preserving the quality of semi-finished rabbit meat products storing for an extended period of time, there have been studied various methods of their cold treatment. The advantage of shock-freezing method over the traditional methods has been justified and its rational parameters have been selected as follows: air temperature not higher than $-30{ }^{\circ} \mathrm{C}$, air velocity $-9.4 \mathrm{~m} . \mathrm{sec}^{-1}$ and relative humidity $-85 \%$; the temperature in the depth of semifinished product after freezing $-10{ }^{\circ} \mathrm{C}$.

The effect of freezing temperature on the duration of cold treatment process has been studied and the regression equations of their relationships have been obtained and regression curves have been constructed. It has been established that unlike traditional method, shock-freezing method reduces $3-3.5$ times the duration of freezing of semi-finished rabbit meat products.

It has been shown that when using the shock-freezing method, mass losses of semi-finished rabbit meat products are minimal and are 5-5.3 lower as compared to traditional method of freezing.

Shock-freezing method allows for improving the functional properties of semi-finished rabbit meat products: by the type of semi-finished products, water binding capacity has increased by $23.2-31.9 \%$, water holding capacity - by $20-25 \%$ and $\mathrm{pH}-$ by $6.7-10.4 \%$.

There have been studied microbiological indicators of frozen semi-finished products and their changes during the storage process. It has been established that they meet the safety and hygiene requirements for meat products.

The full results obtained indicate the advantage of shockfreezing method as compared to traditional methods, as well as point to the appropriateness of its use when selecting the cold treatment modes for semi-finished rabbit meat products.

\section{REFERENCES}

Ali, S., Zhang, W., Rajput, N., Khan, M. A., Li, C. B., Zhou, G. H. 2015. Effect of multiple freeze-thaw cycles on the quality of chicken breast meat. Food Chemistry, vol. 173, p. 808-814. https://doi.org/10.1016/j.foodchem.2014.09.095

Antipova, L. V., Glotova, I. A., Rogov, I. A. 2004. Methods of research of meat and meat products. Moscow, Russia : Kolos. 576 p. ISBN: 5-9532-0187-7.

Bolshakov, S. A. 2003. Холодильная техника $u$ технология продуктов питания (Refrigeration and Food Technology). 304 p. ISBN 5-7695-1229-6. (In Russian)

Erlihman, V. N. 2010. Evaluation of the quality of frozen food during storage. Bulletin of the International Academy of Cold, no. 3, p. 36-38 Available at: https://cyberleninka.ru/article/v/otsenka-kachestvazamorozhennyh-produktov-pri-hranenii
Evans, J. A. 2008. Frozen Food Science and Technology. 1st Edition. Wiley-Blackwell Publishing. 368 p. ISBN 978-14051-5478-9.

Farouk, M. M., Wieliczko, K. J., Merts, I. 2004. Ultra-fast freezing and low storage temperatures are not necessary to maintain the functional properties of manufacturing beef. Meat Science, vol. 66, no. 1, p. 171-179. https://doi.org/10.1016/S0309-1740(03)00081-0

Feiner, G. 2010. Мясныле продуктыл: научные основы, технологии, практические рекомендации (Meat products, scientific foundations, Technologies). St. Petersburg : Profession, 719 p. ISBN 978-5-904757-04-5. (In Russian)

Filippov, V. I., Kremenevskaya, M. I., Kutsakova, V. E. 2014. Технологические основы холодильной технологии nищевых продуктов (Technological basis of food products refrigeration technology). SPb : Giord. 576 p. (In Russian) Available at: https://www.twirpx.com/file/2358710/

Gambuteanu, C., Borda, D., Alexe, P. 2013. The effect of freezing and thawing on technological properties of meat: Review. Journal of Agroalimentary Processes and Technologies, no. 19, no. 1, p. 88-93. Available at: https://www.journal-of-

agroalimentary.ro/admin/articole/48037L15_Vol_19_1_2013 _88-92.pdf

GOST 10444.15-94. 1994. Food products. Methods for determining the amount of mesophilic aerobic and facultativeanaerobic microorganisms.

GOST 30518-97. 1997. Food products. Methods for the detection and determination of the number of bacteria of the Escherichia coli group (coli form bacteria).

GOST 30519-97. 1997. Food products. Methods for the detection of bacteria of the genus Salmonella.

Hip, R. 2007. Охлаждение и продовольственная безопасность (Cooling and Food Safety). (In Russian) Available at: http://www.holodteh.ru/ht/archive/_2007$11 /$ ?cat $=1$

Chwastowska-Siwiecka, I., Kondratowicz, J., Gugolek, A., Matusevičius, P. 2013. Changes in the physicochemical properties of deep-frozen rabbit meat as dependent on thawing method. Vet. Med. Zoot., vol. 62, no. 84, p. 68-72.

Jo, Y. J., Jang, M. Y., Jung, Y. K., Kim, J. H., Sim, J. B., Chun, J. Y., Yoo, S. M., Han, G. J., Min, S. G. 2014. Effect of novel quick freezing techniques combined with different thawing processes on beef quality. Korean J. Food Sci. Anim. Resour., vol. 34, no. 6, p. 777-783. https://doi.org/10.5851/kosfa.2014.34.6.777

Leygonie, C, Britz, T. J., Hoffman, L. C. 2012. Impact of freezing and thawing on the quality of meat: review. Meat Science, vol. 91, no. 2, p. 93-98. https://doi.org/10.1016/j.meatsci.2012.01.013

Onishchenko, V. P., Zheliba, I. A., Zinchenko, V. D. 2011. The state of water in beef meat during its freezing and thawing. Bulletin of the Academy of Cold, no. 2, p. 39-42. Available at: https://cyberleninka.ru/article/v/sostoyanie-vody-v-myasegovyadiny-pri-ego-zamorazhivanii-i-razmorazhivanii

Qian, S., Li, X., Wang, H., Sun, Z., Zhang, C., Guan, W., Blecker, C. 2018. Effect of sub-freezing storage (-6, -9 and -12 ${ }^{\circ} \mathrm{C}$ ) on quality and shelf life of beef. International Journal of Food Science + Technology, vol. 53, no. 9, p. 2129-2140. https://doi.org/10.1111/ijfs. 13800

Rogov, I. A., Zabashta, A. G., Kazyulin, G. P. 2009. Tehnology of Meat and Meat Products. Book 1. General technology of meat. 565 p.

Soroko, O., Usenia, I. 2011. Analysis of methods of freezing food. Science and innovation, vol. 99, no. 5, p. 63-67. 
Swami, J. N., Raut, S. S., Rindhe, S. N. 2015. Effect of freeze-thaw cycle on quality of rabbit meat. Haryana Veterinarian, vol. 54, no. 2, p. 160-163.

Tavdidishvili, D., Khutsidze, T., Tsagareishvili, D., Mamrikishvili-Okreshidze, L. 2018. Studing the impact of non-traitional supplements on the quality of the minced rabbit meat products. Potravinarstvo Slovak Journal of Food Sciences, vol. $12, \quad$ no. $1, \quad$ p. 806-814. https://doi.org/10.5219/982

Tsikin, S. 2012. Development of technology and evaluation of the properties of natural frozen semi-products from meat of wild animals and game. Dissertation theses. Russia, Orel. 148 p. Available at: http://tekhnosfera.com/razrabotka-tehnologiii-otsenka-svoystv-naturalnyh-zamorozhennyh-polufabrikatoviz-myasa-dikih-zhivotnyh-i-dichi

Vieira, C., Diaz, M. Y., Martinez, B., Garcia-Cachan, M. D. 2009. Effect of frozen storage conditions (temperature-and length of storage) on microbial and sensoryquality of rustic crossbred beef at different stages of aging. Meat Science, no. 83, vol. $3, \quad$ p. $398-404$. https://doi.org/10.1016/j.meatsci.2009.06.013

Wang, Z., He, Z., Li, H. 2018. The effect of repeated freezethaw cycles on the meat quality of rabbit. World Rabbit Science, vol. 26, no. 2, p. 165-177. https://doi.org/10.4995/wrs.2018.8616

Yablonenko, L. A. 2008. Investigation of the impact of deep freezing on quality of minced meat semi-finished products. Dissertation. Russia, Ulan-Ude. 123 p. Available at: https://www.dissercat.com/content/issledovanie-vliyaniyaglubokogo-zamorazhivaniya-na-kachestvo-rublenykhmyasnykh-polufabrika

\section{Acknowledgments:}

This work was supported by Shota Rustaveli National Science Foundation of Georgia (SRNSFG) [grant FR 17 -353 "Development of technologies for Producing and Storage of Healthy foods by Using Rabbit Meat"].

\section{Contact address:}

Dodo Tavdidishvili, Akaki Tsereteli State University, Faculty of Engineering and Technology, Department of Food Technology, 59 Tamar Mephe str., 4600 Kutaisi, Georgia, Tel.: +995599432628,

E-mail: drtavdi@gmail.com

ORCID: https://orcid.org/0000-0002-7460-8209

Davit Tsagareishvili, Akaki Tsereteli State University, Faculty of Engineering-Technical, Department of Mechanical engineering, 59 Tamar Mephe str., 4600 Kutaisi, Georgia, Tel.: +995551368683,

E-mail: david.tsagar62@gmail.com

ORCID: https://orcid.org/0000-0001-6941-2167

*Tsira Khutsidze, Akaki Tsereteli State University, Faculty of Engineering and Technology, Department of Food Technology, 59 Tamar Mephe str., 4600 Kutaisi, Georgia, Tel.: +995551412585,

E-mail: cirakh@gmail.com

ORCID: https://orcid.org/0000-0001-5748-856X

Manana Pkhakadze, Akaki Tsereteli State University, Faculty of Maritime Transport, Department of logistics software and information systems - Associate- Professor, 59 Tamar Mephe str., 4600 Kutaisi, Georgia, Tel.: +995577131803,

E-mail: mananafxakadze@mail.ru

ORCID: https://orcid.org/0000-0002-9139-2235

Lana Kvirikashvili, Akaki Tsereteli State University, Faculty of Engineering and Technology, Department of Food Technology, 59 Tamar Mephe str., 4600 Kutaisi, Georgia, Tel.: +995598808872,

E-mail: lanakvirikashvili@mail.ru

ORCID: https://orcid.org/0000-0003-3912-1208

Corresponding author: * 